\title{
血液透析患者の胃粘膜血流量の検討
}

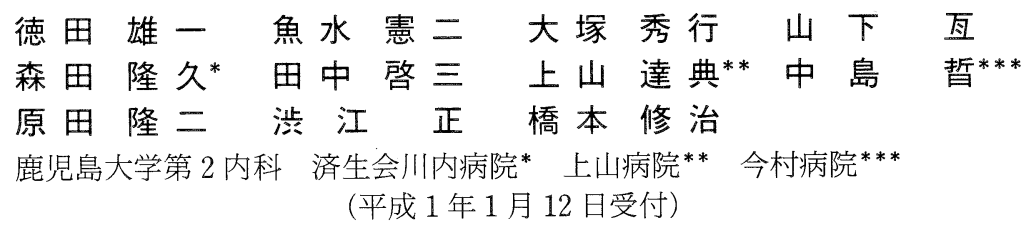

key words: hemodialysis, gastric mucosal lesion, gastric mucosal blood flow, laser doppler flowmeter

〈要旨〉

血液透析患者の胃粘膜病変の発生機序解明のため血液透析患者の胃粘膜血流量を内視鏡下で測定した，対象は，血 液透析患者 28 名 (男性 14 名, 女性 14 名, 年齢 27〜 81 歳) で, コントロール群として胃粘膜病変を認めなかった健 康者 25 名（男性 12 名, 女性 13 名, 年齢 39 78 歳) の胃粘膜血流量を測定した。血液透析患者の胃粘膜血流量は, 胃体上部大弯 $19.8 \pm 6.4 \mathrm{ml} / \mathrm{min} / 100 \mathrm{~g}$, 胃体下部小弯 $18.7 \pm 5.9 \mathrm{ml} / \mathrm{min} / 100 \mathrm{~g}$, 前庭部小弯 $20.4 \pm 6.8 \mathrm{ml} / \mathrm{min} /$ $100 \mathrm{~g}$, 前庭部大弯 $19.0 \pm 8.3 \mathrm{ml} / \mathrm{min} / 100 \mathrm{~g}$ であった。これに対してコントロール群では, 胃体上部大弯 $26.2 \pm 8$. $5 \mathrm{ml} / \mathrm{min} / 100 \mathrm{~g}$, 胃体下部小弯 $24.4 \pm 8.1 \mathrm{ml} / \mathrm{min} / 100 \mathrm{~g}$, 前庭部小弯 $23.0 \pm 7.1 \mathrm{ml} / \mathrm{min} / 100 \mathrm{~g}$, 前庭部大弯 $19.2 \pm$ $5.9 \mathrm{ml} / \mathrm{min} / 100 \mathrm{~g}$ であった。すなわち血液透析患者ではコントロール群に比して胃体部で胃粘膜血流量の低下がみ られ（胃体上部大弯 $\mathrm{p}<0.01$ 胃体下部小弯 $\mathrm{p}<0.05$ ) ストレス性の病変が起こりやすい状態にあると考えられた。し かし, 血液透析患者の胃粘膜病変の多くは胃前庭部に発生しており, このことは胃粘膜血流量では説明できず今後の 検討が必要だと考えられた。

胃粘膜血流量に影響を与える因子としては，血液透析患者では，加齢により胃体部，前庭部共に胃粘膜血流量の低 くなる傾向がみられたが, 性別, 病変の有無による胃粘膜血流量の差はみられなかった。

\section{Gastric mucosal blood flow in hemodialysis patients}

Yuichi Tokuda, M.D., Kenji Uomizu, M.D., Hideyuki Ohtsuka, M.D., Wataru Yamashita, M.D., Takahisa Morita, M.D., ${ }^{*}$ Keizo Tanaka, M.D., Satonori Ueyama, M.D., ${ }^{* *}$ Akira Nakashima, M.D, ${ }^{* *}$ Tadashi Sibue, M.D., Shuji Hashimoto, M.D.

Second Department of Internal Medicine, School of Medicine, Kagoshima University ; Saisei-Foundation Sendai Hospital* ; Ueyama Hospital $^{* *}$; Imamura Hospital***

In an attempt to clarify causes of gastric mucosal lesions in hemodialysis (HD) patients, gastric mucosal blood flows (GMBFs) were endoscopically measured in healthy persons $(n=25)$ and HD patients $(n=28)$ using a laser doppler blood flowmeter. In the gastric antrum, GMBFs of the HD patients (lesser curvature : $20.4 \pm 6.8 \mathrm{ml} / \mathrm{min}$ / $100 \mathrm{~g}$; greater curvature : $19.0 \pm 8.3 \mathrm{ml} / \mathrm{min} / 100 \mathrm{~g}$ ) were almost equivalent to those of healthy persons (lesser curvature : $23.0 \pm 7.1 \mathrm{ml} / \mathrm{min} / 100 \mathrm{~g} ;$ greater curvature : $19.2 \pm 5.9 \mathrm{ml} / \mathrm{min} / 100 \mathrm{~g})$. On the other hand, in the gastric body, the GMBFs (upperbody greater curvature: $19.8 \pm 6.4 \mathrm{ml} / \mathrm{min} / 100 \mathrm{~g}$; lower body lesser curvature : $18.7 \pm 5.9 \mathrm{ml} / \mathrm{min} / 100 \mathrm{~g}$ ) showed lower values than those of healthy persons (upper body greature curvature : $26.2 \pm 8.5 \mathrm{ml} / \mathrm{min} / 100 \mathrm{~g}$; lower body lesser curvature : $24.4 \pm 8.1 \mathrm{ml} / \mathrm{min} / 100 \mathrm{~g}$ ), suggesting that HD patients tend to have stress-induced lesions in the gastric body. However, it is known that gastric lesions in HD patients usually occur in the region of the gastric antrum, and accordingly, GMBF changes are not thought to account for gastric lesions. Further studies are, therfore, required to clarify the causes of gastric mucosal lesions in HD patients.

\footnotetext{
徳田 雄一 鹿児島大学第 2 内科

₹ 890 鹿児島市宇宿町 1208-1（0992-64-2211）
} 


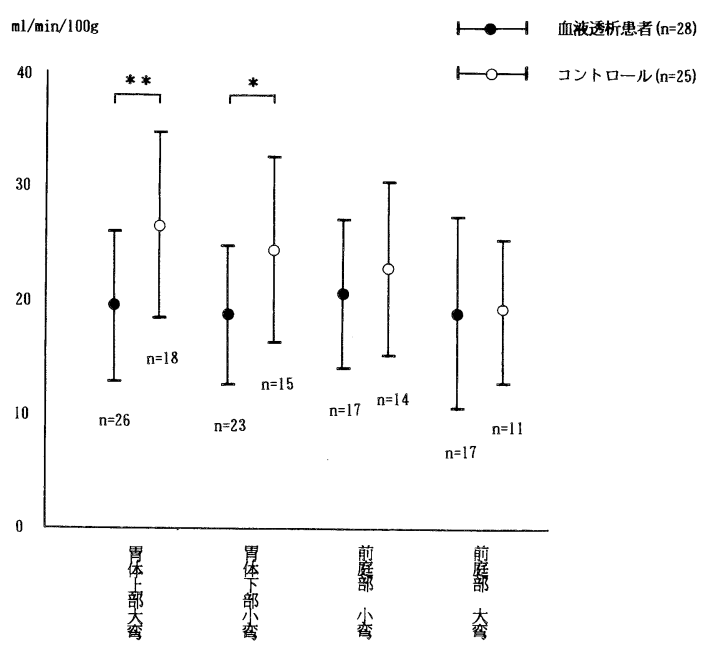

図 1 胃粘膜血流量の測定結果 (mean $\pm \mathrm{SD}$ ) $* * \mathrm{p}<0.01 * \mathrm{p}<0.05$

欲不振, 悪心, 嘔吐等の消化器症状の訴えが多くみられ, 我々は血液透析患者には胃粘膜病変が多いことを，すで に報告してきた ${ }^{1)}$ 今今回我々は，その発生機序解明のため 血液透析患者の胃粘膜血流量を内視鏡下で測定し，対照 群と比較検討したので報告する。

\section{対象・方法}

内視鏡検查の対象は, 血液透析患者 28 名 (男性 14 名, 女性 14 名, 年齢 $27 \sim 81$ 歳) で，コントロール群として 胃粘膜病変を認めなかった健康者 25 名（男性 12 名，女 性 13 名，年齢 $39 \sim 78$ 歳）の胃粘膜血流量を測定した。 胃粘膜血流量の測定には Advance 社の Laser 組織血流 計 ALF2100 を用いて, 内視鏡下に鉗子孔より $2.7 \mathrm{~mm}$ 径 の内視鏡用プローブを插入し，胃粘膜表面へ接触して測 定した。測定部位は胃体上部大弯，胃体下部小弯，前庭 部小弯, 前庭部大弯の 4 か所とし, 測定に際しては内視 鏡的に病変が存在した場合には，病変部を避け正常に近 い粘膜部位を測定した。前処置は通常の内視鏡検查と同 様に行った。また血液透析患者については，年齢別（60 歳末満と 60 歳以上), 性別, 胃粘膜病変の有無別に分け て胃粘膜血流量を比較検討した。

\section{結果}

\section{1) 胃粘膜血流量}

血液透析患者では，胃体上部大弯 $19.8 \pm 6.4 \mathrm{ml} / \mathrm{min} /$ $100 \mathrm{~g}$, 胃体下部小弯 $18.7 \pm 5.9 \mathrm{ml} / \mathrm{min} / 100 \mathrm{~g}$, 前庭部小 弯 $20.4 \pm 6.8 \mathrm{ml} / \mathrm{min} / 100 \mathrm{~g}$, 前庭部大弯 $19.0 \pm 8.3 \mathrm{ml}$ $\mathrm{min} / 100 \mathrm{~g}$ であった.これに対してコントロール群では, 胃体上部大弯 $26.2 \pm 8.5 \mathrm{~m} l / \mathrm{min} / 100 \mathrm{~g}$, 胃体下部小弯 24. $4 \pm 8.1 \mathrm{ml} / \mathrm{min} / 100 \mathrm{~g}$, 前庭部小弯 $23.0 \pm 7.1 \mathrm{ml} / \mathrm{min} / 100$

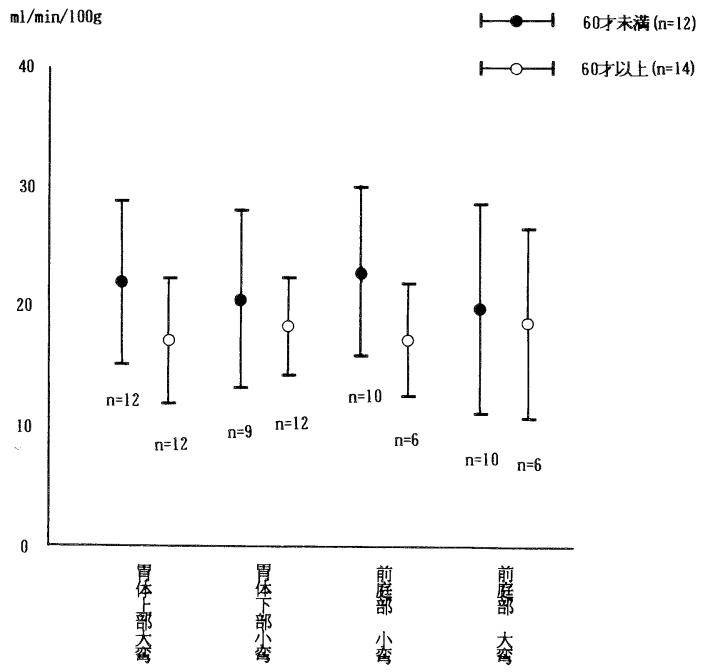

図 2 血液透析患者の胃粘膜血流量一年齢によ る比較一 ( mean $\pm \mathrm{SD})$

$\mathrm{g}$, 前庭部大弯 $19.2 \pm 5.9 \mathrm{~m} l / \mathrm{min} / 100 \mathrm{~g}$ であった。すなわ ち血液透析患者ではコントロール群に比して胃体部で胃 粘膜血流量の低下がみられた（胃体上部大弯 $\mathrm{p}<0.01$ 胃 体下部小弯 $\mathrm{p}<0.05)$.またコントロール群では前庭部よ り胃体部の方が胃粘膜血流量が多いのに対して, 血液透 析患者では前庭部と胃体部とでは，胃粘膜血流量に差は みられなかった（図 1 )。

2 ) 年齢別胃粘膜血流量

血液透析患者を 60 歳未満 $(\mathrm{n}=12)$ と 60 歳以上 $(\mathrm{n}=$ 14）の 2 群に分けて胃粘膜血流量を比較した。6 歳未満 の患者では, 胃体上部大弯 $22.0 \pm 6.7 \mathrm{~m} l / \mathrm{min} / 100 \mathrm{~g}$, 胃体 下部小弯 $20.6 \pm 7.4 \mathrm{ml} / \mathrm{min} / 100 \mathrm{~g}$, 前庭部小弯 $22.7 \pm 7.2$ $\mathrm{m} l / \mathrm{min} / 100 \mathrm{~g}$, 前庭部大弯 $19.9 \pm 8.6 \mathrm{~m} l / \mathrm{min} / 100 \mathrm{~g}$ で あった。これに対して 60 歳以上の患者では，胃体上部大 弯 $17.2 \pm 5.0 \mathrm{ml} / \mathrm{min} / 100 \mathrm{~g}$, 胃体下部小弯 $18.2 \pm 3.9 \mathrm{ml} /$ $\mathrm{min} / 100 \mathrm{~g}$, 前庭部小弯 $17.2 \pm 4.7 \mathrm{ml} / \mathrm{min} / 100 \mathrm{~g}$, 前庭部 大弯 $18.4 \pm 8.2 \mathrm{ml} / \mathrm{min} / 100 \mathrm{~g}$ であった。両者間に有意差 はないが全体的に高齢者では霄粘膜血流量が低い傾向が みられた（図 2 )。

3 ）性別胃粘膜血流量

血液透析患者の胃粘膜血流量を男性群 $(\mathrm{n}=14)$ ，女性 群（ $\mathrm{n}=14 ）$ に分けて比較した。男性群では胃体上部大 弯 $19.8 \pm 6.2 \mathrm{ml} / \mathrm{min} / 100 \mathrm{~g}$, 胃体下部小弯 $19.6 \pm 6.9 \mathrm{ml}$ $\mathrm{min} / 100 \mathrm{~g}$, 前庭部小弯 $20.3 \pm 4.6 \mathrm{ml} / \mathrm{min} / 100 \mathrm{~g}$, 前庭部 大弯 $19.6 \pm 9.2 \mathrm{~m} / / \mathrm{min} / 100 \mathrm{~g}$ であった。これに対して女 性群では, 胃体上部大弯 $19.8 \pm 6.7 \mathrm{~m} / / \mathrm{min} / 100 \mathrm{~g}$, 胃体下 部小弯 $18.0 \pm 5.0 \mathrm{ml} / \mathrm{min} / 100 \mathrm{~g}$, 前庭部小弯 $20.5 \pm 8.6$ $\mathrm{m} l / \mathrm{min} / 100 \mathrm{~g}$, 前庭部大弯 $18.2 \pm 6.7 \mathrm{ml} / \mathrm{min} / 100 \mathrm{~g}$ で 


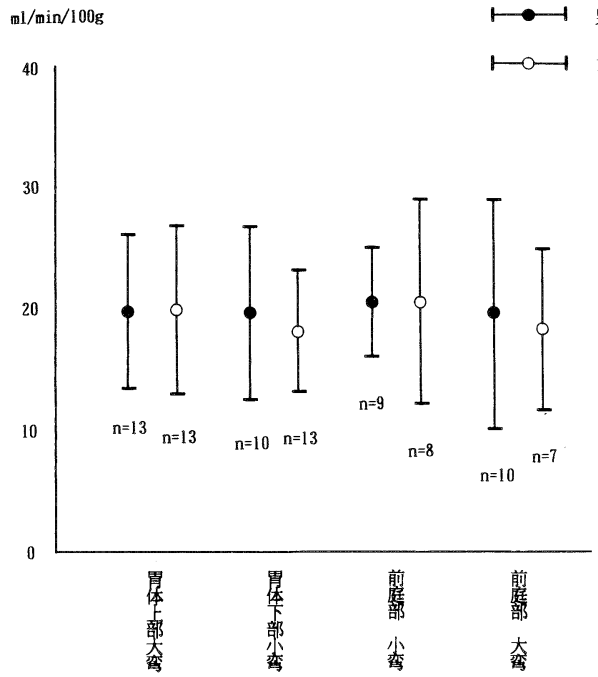

図 3 血液透析患者の胃粘膜血流量一性別による 比較一 $($ mean $\pm \mathrm{SD})$

あった。すなわち性差による胃粘膜血流量に有意差はみ られなかった（図 3 ).

4 ) 病変の有無と胃粘膜血流量

血液透析患者を胃粘膜病変を有する 18 名と胃粘膜正 常の 10 名の 2 群に分けて胃粘膜血流量を比較した. 胃粘 膜病変の内訳は胃潰瘍 2 名, 十二指腸潰瘍 4 名, 急性胃 炎 2 名, 胃びらん 4 名, びらん性胃炎 5 名, 十二指腸炎 5 名であった。

胃粘膜病変群では，胃体上部大弯 $19.4 \pm 7.1 \mathrm{ml} / \mathrm{min} /$ $100 \mathrm{~g}$, 胃体下部小弯 $19.2 \pm 5.4 \mathrm{ml} / \mathrm{min} / 100 \mathrm{~g}$, 前庭部小 弯 $19.5 \pm 4.7 \mathrm{ml} / \mathrm{min} / 100 \mathrm{~g}$, 前庭部大弯 $19.7 \pm 9.1 \mathrm{ml}$ $\mathrm{min} / 100 \mathrm{~g}$ であった.これに対して胃粘膜正常群では, 胃体上部大弯 $20.5 \pm 4.8 \mathrm{ml} / \mathrm{min} / 100 \mathrm{~g}$, 胃体下部小弯 17 . $8 \pm 6.6 \mathrm{ml} / \mathrm{min} / 100 \mathrm{~g}$, 前庭部小弯 $22.6 \pm 9.9 \mathrm{ml} / \mathrm{min} / 100$ $\mathrm{g}$, 前庭部大弯 $17.5 \pm 5.7 \mathrm{ml} / \mathrm{min} / 100 \mathrm{~g}$ であった。すなわ ち両者間で胃粘膜血流量に有意差はみられなかった（図 4 ).

\section{考察}

血液透析患者の胃粘膜病変の成因については，これま でも種々の報告がある. 胃粘膜防御因子の一つである胃 粘膜血流量について高中は2)水素ガスクリアランス法 を，宮本は ${ }^{3)},{ }^{133} \mathrm{Xe}$ クリアランス法を用いて測定し報告 している。高中は血液透析患者の胃粘膜血流量は健常者 より低值を示し，その減少率は前庭部より胃体部におい て，また高齢者より若年者においてより著明であったと 報告している。

宮本は血液透析患者を胃粘膜無所見群と有所見群に分 け, 無所見群では正常対照群に比べ有意差はなかったが,

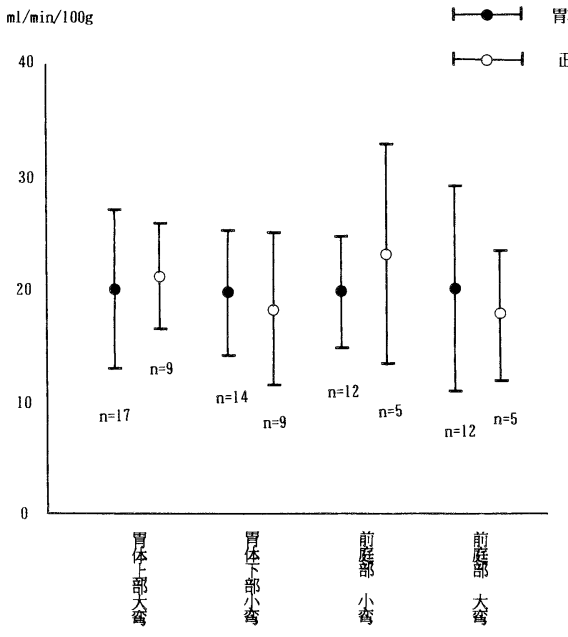

図 4 血液透析患者の胃粘膜血流量一病変の有 無による比較一 $($ mean $\pm \mathrm{SD})$

有所見群では無所見群より有意に減少していたとし，血 液透析による体液量の正常化は胃粘膜における浮腫など の局所の循環障害をとり除き粘膜血流量の増加と粘膜病 変の改善をもたらしたと報告している。今回我々が用い たレーザー血流計の測定原理は, 低出力の $\mathrm{He}-\mathrm{Ne}$ 気体 レーザー光（波長 $632.8 \mathrm{~nm}$ ) が毛細血管内の運動体（主 として赤血球）に反射され，周波数変調（ドップラーシ フト）を受ける現象より赤血球密度とその平均移動速度 の関数として, 主に赤血球の流れを胃粘膜血流量として $\mathrm{m} l / \mathrm{min} / 100 \mathrm{~g}$ 単位にて表示するようになっている (Bonner の理論) ${ }^{4,5)}$. 健常者における胃粘膜血流量につ いては，前庭部より胃体部血流の方が多いと報告されて いる ${ }^{2,6,7)}$. 今回のレーザー血流計による測定でも, コント ロール群では胃粘膜血流量は胃体上部大弯, 胃体下部小 弯, 前庭部小弯, 前庭部大弯の順に多く同様の傾向を示 した。しかし，血液透析患者では胃体上部大弯，胃体下 部小弯, 前庭部小弯, 前庭部大弯共に同様の值を示し, コントロール群との比較では胃体上部大弯, 胃体下部小 弯にて胃粘膜血流量の低下を認めた。このことは，スト レスによる胃粘膜血流量の低下が胃体部に強くストレス 性の AGML や胃潰瘍が胃体部におこりやすいというこ $と^{8 \sim 10)}$, 血液透析患者では，急性胃炎などの AGML が 多いということ年11,12)を考え合わせると，血液透析患者で は健常人よりもストレス性の病変が発生しやすい状態に あると考えられた。しかし，血液透析患者の胃粘膜病変 の多くは胃前庭部に発生しており ${ }^{1,13)}$ ，このことは胃粘膜 血流量では説明できず今後の検討が必要だと考えられ た。 
血液透析患者における胃体部での胃粘膜血流量低下の 原因としては, 胃体部（胃底腺領域）と前庭部（幽門腺 領域）では血管構築が異なり, 毛細管の分布密度が胃底 腺領域では幽門腺領域の 2 倍になっており, 逆に血管径、 が小さいことょり末梢血管抵抗が約 3 倍になっているこ とにより ${ }^{14)}$, 粘膜の浮腫やうっ血の影響を受けやすいこ と。またストレス負荷時には胃底腺領域の細動脈レベル の狭小化が著明であり ${ }^{14)}$ ，胃底腺領域はストレスの影響 を受けやすいことなどが考えられた，以上のように血液 透析患者においては, 胃体部において胃粘膜血流量の低 下した状態にあり AGML 等のストレス性の胃粘膜病変 のおこりやすい状態にあるといえる。胃粘膜血流量に影 響を与える因子としては，血液透析患者では，加齢によ り胃体部, 前庭部共に胃粘膜血流量の低くなる傾向がみ られたが, 性別, 病変の有無による胃粘膜血流量の差は みられなかった。

\section{結論}

1 ）血液透析患者の胃粘膜血流量を測定した.

コントロール群との比較で, 胃体部で胃粘膜血流量の 低下がみられ, 血液透析患者では, ストレス性の病変が 起こりやすい状態にあると考えられた. しかし, 血液透 析患者の胃粘膜病変の多くは胃前庭部に発生しており, このことは胃粘膜血流量では説明できず今後の検討が必 要だと考えられた。

2) 血液透析患者では, 加齢により胃体部, 前庭部共 に胃粘膜血流量の低くなる傾向がみられた。

3 ) 血液透析患者では性別による胃粘膜血流量の差は みられなかった。

4 ）血液透析患者では胃粘膜病変の有無による胃粘膜 血流量の差は前庭部, 胃体部ともにみられなかった。 文献

1）德田雄一, 山下 互, 森田隆久, 田中啓三, 中島 晢, 原田隆二, 渋江 正, 橋本修治：血液透析患者にお ける上部消化管病変の内視鏡的検討, 医学研究 58, : 417-420, 1988

2）高中芳弘：血液透析患者の胃粘膜病変と胃粘膜血流 量についての研究. 日大医誌 $46: 297-304,1987$

3）宮本一行：慢性腎不全患者に打ける胃粘膜病変と胃
血流量, とくに血液透析の胃血流量に及ぼす影響に ついて, 横浜医学 $38: 423-427,1987$

4) R F Bonner, T R Clem, P D Bowen, R L Bowman: Laser-Doppler continuous real-time moniter of pulsatile and mean blood flow in tissue microcirculation. In "Scattering Techniques Applied to Supramolecular and None Quilibrium Systems (NATO ASI series B, Vol 73)" ed., Chen S H, 685-702, Plenum Publishers, New York, 1981

5）鹿嶋 進, 橋爪俊幸, 満井顕太郎: レーザー血流計 の特性, 日本レーザー医学会誌 $9 ： 3-7,1988$

6) Kamada $T$, Kawano $S$, Sato $N$, Fukuda $M$, Fusamoto H, Abe H: Gastric mucosal blood distribution and its changes in the healing process of gastric ulcer, gastroenterology 84 : 1541-1546, 1983

7）宮本二朗, 中原 朗：胃潰瘍における胃血行動態. Progress of Digestive Endscopy 24:42-46, 1984

8）中村紀夫, 長尾房大: 急性胃粘膜病変の病理, 臨床 消化器内科 $3: 1379-1385,1988$

9）中村紀夫, 坂口友次朗, 長洲堯雄, 田村茂樹, 小山 厚, 原 伸一, 小野敏孝, 長尾房大: 急性胃病変と 胃粘膜血流，Prog Med 2:289-296, 1982

10）中村紀夫, 田村茂樹：急性胃粘膜病変の病態と治療 方針, 腹部救急診療の進歩 $7: 1$ - 9, 1987

11) Tani N, Harasawa S, Suzuki S, Miwa M, Sakita R, Nomiyama T, Watanabe H, Senoue I, Kikuchi $\mathrm{K}$, Miwa $\mathrm{T}$ : Lesions of the upper gastrointestinal tract in patients with chronic renal failure, Gastroenterologia Jpn $15: 480-484,1980$

12) 武藤重明, 浅野 泰, 酒井秀朗, 木村 健, 宮田道 夫：慢性腎不全患者に抢ける胃液分泌能抒よび胃粘 膜内ガストリン值の検討。消化管ホルモン (IV) : 1 - 9, 1984

13）横山健郎, 蜂巣 忠: 腎と消化管 (胃を中心に), 腎 と透析 $7: 432-437,1979$

14）長尾房大, 中村紀夫 : 胃粘膜血流と胃病変. 胃粘膜 血流の基礎と臨床, 羊土社, 東京 : 31-38, 1983 